\title{
GROŽIO IR SVEIKATOS PREKIŲ VARTOTOJŲ LOJALUMO VERTINIMAS SOCIALINIŲ TINKLŲ ERDVĖJE
}

\author{
Vilmantė LEIŠYTË*, Valentina PELECKIENÉ \\ Vilniaus Gedimino technikos universitetas, Verslo vadybos fakultetas, \\ Vadybos katedra, Sauletekio al. 11, LT-10223, Vilnius, Lietuva \\ "El.paštas vilmante.leisyte@stud.vgtu.lt
}

\begin{abstract}
Santrauka. Straipsnyje siekiama ištirti, kaip galima pasiekti ir išlaikyti vartotojų lojalumą grožio ir sveikatos prekėms per socialinių tinklų prizmę. Nors yra nemažai tyrimų apie vartotojų lojalumą, tačiau tyrimų kiekis vertinant vartotojų lojalumą per socialinių tinklų erdvę yra labai ribotas. Ištirtoje literatūroje aptariama, kad vien klientų pirkimas nèra geriausias ilgalaikès sėkmės būdas, taip pat svarbu sukurti vertę vartotojams. Šiame tyrime pateikiami vartotojų lojalumo santykiai su įmone per socialinių tinklų erdvę, nagrinejjamas vartotojų elgesys ir prekès ženklo naudojimosi internete priežastys. Tyrimui naudojami ekspertinio vertinimo ir TOPSIS metodai. Tyrimų rezultatais aktyvus įmonès sekimas socialiniuose tinkluose stimuliuoja vartotojų lojalumą, pasitikejjimą ir pajamų apyvartą. Tyrime yra neišvengiami apribojimai. Apibendrinti rezultatai ateityje gali tapti nesvarbūs dèl technologijos pokyčių. Atsižvelgiant ị tai, kad socialinių tinklų svetainès yra naujas reiškinys, galimi tolesni tyrimai.
\end{abstract}

Reikšminiai žodžiai: vartotojų lojalumas, grožio ir sveikatos prekès, prekės ženklas, socialiniai tinklai, TOPSIS, ekspertinis vertinimo metodas.

\section{Ivadas}

Tyrimo aktualumas. Kiekvieno verslo sėkmė priklauso nuo klientų pasitenkinimo. Ypač verslo pradžioje ị klientus orientuojamasi pirmiausia, o paskui i pelną. Amerikos verslininkas Sam Walton yra sakęs „yra tik vienas viršininkas. Klientas - ir jis gali atleisti visus kompanijos narius nuo pirmininko žemyn, tiesiog išleisdamas pinigus kur nors kitur“ (Walton, 1990). Šių dienų skaitmeniniame pasaulyje, klientų pasitenkinimas yra vienas iš reikšmingiausių verslo sẻkmès komponentų ir tuo pat metu vaidina gyvybiškai svarbų vaidmeni plečiant rinkos vertę. Bendrovès, kurioms pavyksta visiškai patenkinti savo klientus, išliks aukščiausiose rinkos dalyse. Tačiau ši užduotis yra sudètinga dèl nuolat augančių klientų poreikių aukštos kokybẻs prekèms ir paslaugoms, dèl to yra svarbu sukurti ryšĭ su klientais, stiprinti jų lojalumą įmonės ar prekẻs ženklo atžvilgiu. Išmaniujų technologijų ir socialinių tinklų laikais palaikyti ryšius su vartotojais nebęmanoma vien tik sukuriant geresnį produktą ar paslaugą, juos galima pasiekti sukuriant emocinę vertę. Dẻl plataus socialinių tinklų reiškinio masto komunikacijos įrankiai tarp vartotojų ir ịmonių gerokai pasikeité, dẻl to ịmonès turi pertvarkyti verslo santykių palaikymo strategiją (Nisar ir Whitehead, 2016). Nors yra nemažai tyrimų apie vartotojų pasitenkinimą ir lojalumą, yra labai mažai atliktų tyrimų apie vartotojų lojalumą per socialinių tinklų svetaines prizmę, kadangi socialinių tinklų fenomenas tęsiasi tik apie dešimtmetị (Feng et al., 2019). Dèl to šio darbo tikslas yra ištirti, kaip vartotojų lojalumas gali būti igytas ir išpuoselètas per socialinių tinklų erdvę.

\section{Teoriniai vartotojų lojalumo ir socialinių tinklų aspektai}

\subsection{Vartotojų lojalumas ir jo svarba}

Mokslinėje literatūroje vartotojų lojalumas yra sąlyginai plačiai ištyrinètas, tačiau vis dar ieškomi būdai kaip tiksliai ir aiškiai reiktų apibrèžti šią sąvoką, ir tai reiškia, kad vis dar neturime visuotinai priimto apibrěžimo (Nisar ir Whitehead, 2016). Autorių vartojami apibrěžimai yra sugrupuoti 1 lentelèje, dažniausiai minimi požymiai literatūroje susiję su vartotojų lojalumu - pakartotinis pirkimas, vartotojų pasitenkinimas, emocinis ryšys, rekomendacija kitiems. Atlikus literatūros šaltinių turinių analizę siūlau apibrěžimą sujungiantị kitų autorių mintis. Kadangi dažniausiai literatūroje pateikiama formuluote yra arba tik iš vartotojo arba tik iš įmonès pusès, tad sujungus dvi šias grupes galima teigti jog vartotojo lojalumas tai vartotojo emocinis prisirišimas su įmone, 
ịsitraukimas ir buvimas ịmonès dalimi sekant pokyčius, o ịmonei vartotojo lojalumas - atgalinio ryšio pasekmė skatinanti įmonès plètrą finansų, ekonomikos bei inovacijų srityse.

1 lentelè. Autorių apibrèžimai apie vartotojų lojalumą literatūroje

\begin{tabular}{|c|c|}
\hline Autorius & Apibrèžimas \\
\hline (Mohammadi, 2015) & $\begin{array}{l}\text { „Vartotojo ịsipareigojimas užmegzti verslą su tam tikra organizacija, pakartotinai perkant jų } \\
\text { prekes ir paslaugas bei rekomenduojant paslaugas ir produktus draugams ir partneriams“. }\end{array}$ \\
\hline (Nisar ir Whitehead, 2016) & „Daugumai kompanijų klientų lojalumas tik pakartotiniai pirkimai“. \\
\hline (Oliver, 1999) & $\begin{array}{l}\text { İsipareigojimas ateityje nuosekliai pirkti pageidaujamą produktą ar paslaugą ir taip sukelti } \\
\text { pakartotinius to paties prekès ženklo pirkimus, nepaisant situacijos ir rinkodaros pastangų, } \\
\text { galinčiu sukelti elgesio keitimą. }\end{array}$ \\
\hline (McKenna ir Bargh, 1999) & „Vartotojas turi tam tikrą lojalumo laipsnį, kai jie teigiamai vertina prekès ženklą“. \\
\hline (Koetz, 2019) & $\begin{array}{l}\text { „Pasitenkinimas nebūtinai sukuria lojalumą, nes susidomėjimas produktu gali išblèsti. } \\
\text { Svarbiau sukurti ịsimintinas vartojimo patirtis, kad pradžiugintų vartotojus ir tokiu būdu } \\
\text { užmegztų su jais emocinius ryšius. }\end{array}$ \\
\hline $\begin{array}{l}\text { (Cossío Silva ir Revilla } \\
\text { Camacho, 2016) }\end{array}$ & $\begin{array}{l}\text { Lojalus klientas - fizinis ar juridinis asmuo, perkantis prekes ar paslaugas ir nėra linkęs pirkti } \\
\text { iš konkurentų. }\end{array}$ \\
\hline $\begin{array}{l}\text { (Sangeetha ir Jawahar Ran, } \\
\text { 2015) }\end{array}$ & $\begin{array}{l}\text { Lojalumas gali būti analizuojamas tiek iš ịmonès, tiek iš vartotojo perspektyvos. Akademinių } \\
\text { darbų, kuriuose išdėstoma koncepcija kaip rinkodaros pastangų rezultatas. Mūsų nuomonè } \\
\text { yra, kad dvi perspektyvos turi būti analizuojamos kaip visuma, o ne kaip atskiros to paties } \\
\text { proceso dalys. }\end{array}$ \\
\hline (Blut et al., 2007) & $\begin{array}{l}\text { Egzistuoja trys populiarios lojalumo koncepcijos: lojalumas kaip požiūris, sukuriantis ryšị su } \\
\text { prekès ženklu; ištikimybe, išreikšta vartotojo elgesiu; ir pirkti moderuojančios individo } \\
\text { charakteristikos, aplinkybės ir / ar pirkimo situaciją. }\end{array}$ \\
\hline (Craig, 2007) & $\begin{array}{l}\text { Lojalūs klientai yra tie, kurie teigiamai vertina įmonę, issipareigoja atpirkti produktus ar } \\
\text { paslaugas ir rekomenduoti produktą kitiems, skatinanti „,word of mouth“ reklamą. }\end{array}$ \\
\hline
\end{tabular}

Konkurencingoje rinkoje, norint išlaikyti vartotojus, svarbu gerai išvystyti santykius. Vienas iš būdų palaikyti gerus santykius su vartotojais yra užtikrinti aukštos kokybęs klientų aptarnavimą. Vartotojams suteikiama pagalba operatyviai reaguojant $\mathfrak{i}$ jų poreikius ar skundus atsakant $\mathfrak{i}$ iškilusius klausimus ar problemas. Vartotojai, kurie gauną kokybišką ir orientuotą i vartotoją aptarnavimą, palankiau vertins įmonę ir bus labiau patenkinti. Tačiau vartotojui nepakanka būti patenkintu ịmone ar prekės ženklu, kad taptu lojaliu vartotoju (Kim et al., 2016). Iš tiesu ir labai patenkintas vartotojas ịmone gali bet kada palikti ją dèl geresniu pasiūlymų. Literatūroje išskiriami dvi kryptys dèl ko vartotojai nors ir būdami patenkinti ịmone gali nebesinaudoti įmonès paslaugomis: alternatyvos patrauklumas ir keitimo kaina. Alternatyvos patrauklumas pasireiškia, kai konkurentai atkreipia esamų vartotojų dèmesị ir susidomėjimą. Šio tyrimo objekto pavyzdžiu grožio ir sveikatos prekių pardavejjai ar gamintojai konkuruoja dèl ekologiškos produkcijos, unikalių prekių, žinomų prekès ženklų. Didejjanti pasiūla rinkoje ir konkurentams pasiūlant geresnius produktus ir paslaugas, konkuruojančių gamintojų patrauklumas didèja, o tai sumažina vartotojų lojalumo lygị esamiems pardavėjams ar gamintojams. Priešingai, jei kiti pardavèjai ar gamintojai negali pateikti kitokių ar geresniu produktų ir paslaugų, pirkejjai liks su dabartiniais tiekejjais. Kuo aukštesnis alternatyvos patrauklumo lygis, tuo žemesnis klientų lojalumo lygis (Kim et al., 2016). Keitimo kaina apima pinigines, psichologines ir laiko sąnaudas, atsirandančias dèl pirkimo produkto ar paslaugos iš kito gamintojo ar pardavèjo. Pavyzdžiui pereinant iš vieno gamintojo ar pardvèjo prie kito gali atsirasti prekès naudojimo sistemu skirtimai, tarkim perkant telefoną ar automobilį. Šis aspektas grožio ir prekių pardavejjams ar gamintojas yra labai svarbus, nes perèjimo pas kitą pardavèją kaina yra žema, kuri padidina konkurenciją. Jeigu perèjimo kaina bus didelè, vartotojai bus linkę išlikti ištikimi ir likti su dabartiniu gamintoju ar pardavejju. Kuo didesnè perèjimo kaina, tuo didesnis vartotojų lojalumas.

Pagal Jay Kandampully, Dwi Suhartanto, Paul Valentin Ngobo ir kitus autorius (Kandampully ir Suhartanto, 2000) (Ngobo, 2017), (Nisar ir Whitehead, 2016) teigiama, kad yra du klientu lojalumo aspektai: elgsenos ir požiūrio. Vartotojo elgesio aspektas parodo pakartotinus pirkimus, o požiūrio aspektas išreiškiamas emocija, kuri yra susijusi su ketinimu rekomenduoti produktą ar paslaugą kitiems. Tačiau pakartotiniai pirkimai ne visada reiškia tvirtą atsidavimą dèl to jie neprilygsta lojalumui. Pavyzdžiui jei visada vartotojas perka iš tos pačios įmonès tai nereiškia kad vartotojas yra lojalus, jeigu netoli atsidarytų tos pačios industrijos parduotuve su patrauklesniais pasiūlymais, tikètina, kad vartotojas pereis prie geresnių pasiūlymų. Nors elgsenos aspektas yra populeresnis, nes jis lengviau suvokiamas ir išmatuojamas, visada svarbu ivvertinti abu lojalumo aspektus.

Pardavėjams ar gamintojams vartotojų lojalumas suteikia daug naudos konkurenciniui pranašumui. Žinoma, kad vartotojų lojalumas ir pelningumas turi teigiamą ryšị, tyrime (Reichheld, 2001) nustatyta, kad įmonès pelną galima padidinti maždaug nuo $25 \%-95 \%$, pagerinus tik $5 \%$ jos klientų išlaikymo procentą. Lojalūs vartotojai yra 
mažiau jautrūs kainos pokyčiams ir perka daugiau. Klientų aptarnavimas nukreiptas i lojalius vartotojus yra pigesnis nei ị naujus klientus, nes lojalūs klientai susipažinę su prekės ženklu, bendra ịmonès informacija. Kitas didelis privalumas turint lojalų klientą yra jų dalijimasis patirtimi apie mėgstamą prekès ženklą ir rekomendacija kitiems. Lojalių vartotojų teigiamų žodžių sklaida veikia kaip rinkodaros šaltinis, stipri reklama. Bill Gates yra pasakęs „Labiausiai nepatenkinti klientai yra didžiausias mokymosi šaltinis“. İmonès tobulẻjimo procesui ypač svarbu tai, kad lojalūs vartotojai yra linkę skųstis nemalonia patirtimi ar kažkokiu trūkumu, tikèdamiesi, kad bus atsižvelgta i jų lūkesčius.

\subsection{Socialinai tinklai ir jų svarba}

Pasaulinis socialinių tinklų naudojimasis auga, $2019 \mathrm{~m}$. vartotojų kiekis siekè 2,96 milijardų, o tai yra 38.4 proc. visos žmonių populiacijos pasaulyje. 1 paveikle pavaizduota chronologija per pastaruosius 10 metų, kaip augo populiacija ir socialinių tinklų vartotojų skaičius.

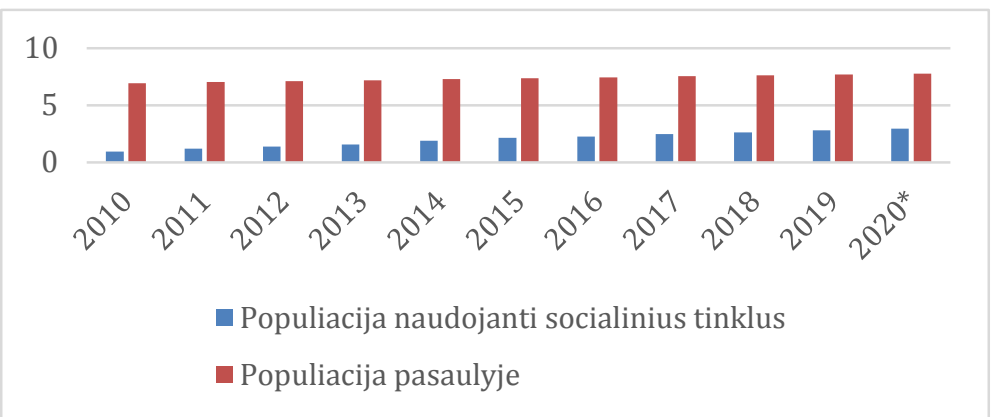

1 paveikslas. Populiacijos ir naudojančiu socialinius tinklus vartotojų chronologija, milijardais (Statista, 2019)

Socialiniai tinklai pakeite žmonių bendravimo tarpusavyje ir su įmonėmis būdą (Asperen et al., 2018). Imonèms tampa vis svarbiau išlikti patraukliems klientams, užmegzti su jais ryšius ir stiprinti jų lojalumą. Socialiniai tinklai laikomi tokių santykių puoselejjimo priemone, pavyzdžiui, sukuriant prekių ženklų gerbèjų puslapius socialinio tinklo svetainėse, tokiose kaip „Facebook“ „Twitter“ ir „Instagram“. Nors įmonès puoselèja socialinių tinklų pritaikymą, vis dar nèra daug ištirta apie socialinių tinklų ịtaką vartotojų lojalumui (Zeng ir Gerritsen, 2014). Socialinių tinklų rinkodara versle labai populiari ir šiais laikais galima teikti, kad būtina, nes tai kainuoja sąlyginai mažiau ir suteikia didelę vertę. Tinklai „Facebook“, „Twitter“ „Instagram“ ir kiti įmonėms atveria galimybę patogiau pateikti savo produkciją, kurią klientai gali pasiekti 24/7, padidinti pardavimus, padidinti ekspoziciją, plèsti verslo partnerystes, generuoti potencialius klientus, padidinti srautą ir pateikti įžvalgą rinkoje. Atliktame tyrime (Erdogmus ir Cicek, 2012) nustatant ryšị tarp socialinès medijos ir lojalumo prekès ženklui, buvo nustatytos priežastys, kodèl vartotojai renkasi socialinių tinklų erdvę. Buvo nustatyta, kad didžiausią ịtaką daro palanki reklama, dažnai atnaujinamas aktualus turinys, draugų siūlomas turinys, platformų įvairove ir bendra informacija ar pirkimo galimybès. Taip pat tyrime buvo nustatytas teigiamas ryšys tarp bendravimo su vartotoju per socialinius tinklus ir teigiamo prekès ženklo vertinimo, o vartotojų sukurtas teigiamas turinys socialinių tinklų erdvèje teigiamai veikia tiek prekès ženklo nuosavybę, tiek požiūrị i prekès ženklą.

Socialiniai tinklai suteikia vartotojams preigą prie nesibaigiančios informacijos rinkimo ir suvartojimo. Tai leidžia asmenims tiesiogiai bendrauti su bet kuo visame pasaulyje, su kuriais jie galbūt niekada negalèjo bendrauti. Socialinèje erdvėje didelị populiarumą turintys ,,influenceriai“, žinomi visuomenei asmenys turi galimybę užmegzti tvirtus ryšius su savo sekèjų bendruomene ir tiesiogiai bendrauti bei reaguoti i juos. İmonès bendradarbiauja su žinomais socialinèje erdveje asmenimis ir reklamuoja savo produkcija jų bendruomenei. Tokiu būdu vykdoma rinkodara suteikia įmonėms pranašumą per tikslines auditorijas, kuri pasiekiama per žmones reklamuojančius i̇monès produkciją. Vartotojai sekdami žinomus asmenis yra labiau linkę ị prekès ženklą, nes pasitiki reklamos šaltiniu. Remiantis „Twitter“ ir „Annalect“ skaitmeninès analizès duomenimis (Baramidze, 2018), 40 \% apklaustų respondentų įsigijo produktą, nes mate jị sekamo ,influencerio“ reklamoje. Populiari reklamos strategija socialinėse platformose yra įžymybių teigiama nuomonè ir atsiliepimai apie prekę ar pardavèją. İžymybès sukuria perdavimo procesą, kurio metu daro įtaką teigiamam vartotojų jausmui dèl produktų ar prekès ženklų. Augant ,influencerių“ bendruomenei socialiniuose tinkluose, įmonès suteikia šiems konkretiems asmenims didžiuli socialinị kapitalą, pagrįstą jų turimų pasekėjų skaičiumi. „Influenceriai“ iš esmès tampa prekès ženklų atstovai - realūs žmonès, iš kurių vartotojai gali gauti nuomonių. Nepaisant to, ar influencerių įrašus remia prekès ženklai, ar ne, jų turinys daro didelę ịtaką pirkimo sprendimams. Jei ,influenceris“ pasidalins įrašu socialiniuose tinkluose apie produktą, kuris jiems tinka, jų auditorija bus labiau suinteresuota sužinoti apie produktus, kad būtų pasiekti tie patys rezultatai. Daug sekejjų turintys asmenys siekia karjeros socialiniuose tinkluose didindami savo auditorijos kiekị ir stengiasi 
ịtikinti, jog jų turinys padeda auditorijai. Jie tinkamai ịtraukia naudojamų produktų prekès ženklą i savo žinutes, pažymėdami prekès ženklą, o tai sekèjams palengvina produktų pirkimą ir pažintį su prekès ženklu.

Grožio industrija toliau plečiasi ir tampa vis ịvairesnè, įtraukdama kiekvieną lytị, rasę ir amžiaus grupę; kartu su tuo turi vystytis ir jos rinkodaros strategijos. Šiandienos visuomenès vartotojai nenori būti ịtraukiami ị tradicines reklamas, kurios žada nerealius lūkesčius. Vartotojai nori pamatyti realius reklamuojamų produktų rezultatus ir kokių tikslių rezultatų gali tikètis patys. Grožio industrijoje išpopuliarèję nemokami produktų paketai siunčiami „,influenciariams“ kad jie galètų naudotis ir peržiūrèti patys produktai prieš dalijantis jų internetinèms bendruomenėms. Mainais už nemokamus produktus iš influencerių reikalaujama paskelbti produkto apžvalgą savo socialinių tinklų paskyroje, kad apžvalga būtų paskleista auditorijai. Tai padeda skatinti informuotumą ir pardavimus. Prekès ženklai platina naujus produktus „influenceriams“ stengiasi suasmeninti, kad pritrauktų dèmesi ir labiau būtų linkę išmėginti nemokamą gaminị.

Labai populiarios grožio ir sveikatos prekių turinio platformos yra „Instagram“ ir „YouTube“. Šios platformos yra didelis šaltinis vartotojams, norintiems gauti daug ir kokybiškos informacijos. 2016 m. „Youtube“ platformoje buvo apie 59 milijardų su grožiu susijusių vaizdo ịrašų peržiūrų, o $2018 \mathrm{~m}$. skaičius viršijo net 169 milijardų peržiūrų (Statista, 2019). Didelę dali turinio susijusio su grožiu platformoje kontroliuoja ir sukuria tinklaraštininkai - „,vlogeriai“. Itakingos skaitmeninès įžymybès, tokios kaip tinklaraštininkai, atstovauja virtualioms bendruomenèms ir vaidina svarbių nuomonès formuotojų vaidmenị, padėdamos ịmonèms stebėti naujas vartotojų tendencijas, kurios, savo ruožtu, leidžia pastarosioms palaikyti naujus klientų poreikius (Hwang ir Zhang, 2018).

Nuo pat pradžių „YouTube“ įsitvirtino kaip garsi socialinių tinklų platforma. Vaizdo ịrašai apie makiažą ir kitus grožio produktus, yra nepaprastai populiarūs „YouTube“ platformoje. Patogi platformos terpè skatina vartotojus kurti savo turinį, skatinant kūrybiškumą ir naujumą. Vaizdo įrašas kaip socialinè terpe gerai koreliuoja su grožio industrija; grožio produktai yra labai vizualūs spalvų, pigmentų ir faktūrų atžvilgiu, todèl „YouTube“ yra puiki platforma, kur juos rodyti. Gebejjimas produktus pateikti vizualiai, ne vien tik įrašant produkto aprašymą, kaip naudoti produktus, įtikina vartotoją mokymosi metodu, kad produktas jiems tiks. Skirtingai nuo tradicinių laikmenų, „YouTube“ leidžia kiekvienam vartotojui būti lygiam, jie neprivalo būti profesionalai, norèdami sukurti savo turinį. Tai suteikia galimybę kiekvienam turèti galimybę naudotis platforma ir pasidalyti savo nuomone apie grožio pramones bei gaminius. Vaizdo įrašams nereikia atrodyti profesionaliai, tačiau tiems, kurie šiandien naudoja „YouTube“ platformą kaip karjerą, pagerina įrašų vaizdo ir garso kokybę, vizuališkai redaguoja įrašą, Šio turinio kūrejjų sekejjai ir vartotojai, ieškantys produktų rekomendacijų, naudojasi šiais vaizdo įrašais, nes juose rodomas turinys yra asmeniškas. Jei vartotojai pasitiki vaizdo įrašo turiniu ir tais, kurie jiems pataria, vartotojai yra labiau linkę įsigyti produktą, o ne klausysis didelių korporacijų skelbimo pirkti produktą.

\section{Tyrimo metodologija}

Tyrimui buvo panaudoti du tyrimo metodai. Pirmasis metodas - ekspertų vertinimo metodas, kuris yra tinkamas duomenų patikrinimui arba pagrindimui. Šio metodo duomenų surinkimui buvo atliktas apklausos anketavimo būdas. Tyrimui buvo sudaryta ekspertų grupé iš 4 ekspertų. Ekspertams keliami reikalavimai kompetencijai patvirtinti buvo: asmenine informacija (vardas, pavardè, kontaktiniai duomenys), išsilavinimas (kvalifikacinis laipsnis, mokslo laipsnis, užsienio kalbų mokejjimas). Tikrinti ekspertų kompetencijos koeficientą naudosime formules pateiktas žemiau:

$$
\begin{gathered}
K_{i}^{0}=\frac{1}{m}, \mathrm{i}=1, \ldots, m ; \\
X_{j}^{t}=\sum_{i=1}^{m} K_{i}^{t-1} \times x_{i j}, j=1, \ldots, n ; \\
\lambda^{t}=\sum_{j=1 i=1}^{n} \sum_{i=1}^{m} x_{j}^{t} \times x_{i j} ; \\
K_{i}^{t}=\frac{1}{\lambda^{t}} \times \sum_{j=1}^{n} x_{j}^{t} \times x_{i j}, \sum_{i=1}^{m} K_{i}^{t}=1,
\end{gathered}
$$

čia: $K$ - ekspertų kompetencija, Xtj-grupinai įverčiai, $x_{i j}$ - rangų suma, $\lambda$ - lambda, $\mathrm{m}$ - ekspertų skaičius.

Gautas reikšmes reikia įstatyti ị galutinę 5 formulę ir patikrinti ar visi kompetencijos koef. Patenka ị gautą intervalą. Jeigu ị kompetencijos koef. neiceina i intervalą, tuo atveju eksperto vertinimai negali būti naudojami tolimesniam vertinimui.

$$
K_{i}^{t}-1,96 S \leq K_{i}^{t} \leq K_{i}^{t}+1,96 S,
$$

čia: $K$ - ekspertų kompetencija, $S$-standartinis nuokrypis. 
Ekspertinio vertinimo prielaida yra ta, kad sprendimas gaunamas tik esant ekspertų nuomonių suderinamumui, dèl to tyrime taikysime Kendall konkordancijos koeficientą (Legendre, 2005). Skaičiuojant ši koeficientą ekspertų vertinimai ranguojami. Turime $m=4$ ekspertus, kurie įvertino 7 alternatyvas, $k=7$. Pirmiausia kiekviename stulpelyje esančios reikšmės keičiamos rangais. Tikrinama, ar ekspertų vertinimai dera tarpusavyje. Suformuluojamos hipotezes:

$\mathrm{H}_{0}$ : ekspertų vertinimai prieštaringi, konkordancijos koeficientas lygus nuliui;

$\mathrm{H}_{1}$ : ekspertų vertinimai panašūs, konkordancijos koeficientas nelygus nuliui.

Nuokrypio nuo rangų vidurkio kvadratų suma apskaičiuojama 6 formule.

$$
S^{2}=\sum_{j=1}^{k}\left(\sum_{j=1}^{m} x_{i j}-a\right)^{2},
$$

čia: $S^{2}$ - nuokrypių vidurkių kavdratas, $x_{i j}$ - rangų suma, $a$ - rangų sumų vidurkis.

Apskaičiavus nuokrypio nuo rangų vidurkio kvadratų sumą reikia patikrinti didžiausią galimą reikšmę. Svarbu, kad apskaičiuota suma būtų tame intervale. Naudojant 7 formulę apskaičiuojama didžiausia galima nuokrypio nuo rangų vidurkio kvadratų suma kai galimi sutampantys rangai.

$$
S_{\max }^{2}=\frac{m^{2}\left(k^{3}-k\right)-m \sum_{i=1}^{r} T_{k}}{12},
$$

čia: $S^{2}$ - nuokrypių vidurkių kavdratas, $m$ - ekspertų skaičius, $k$ - alternatyvų skaičius, $T_{k}$ - sutampančių rangų skaičius k-tajai grupei.

$$
T_{k}=\sum_{q=1}^{u}\left(t_{q}^{3}-t_{q}\right),
$$

čia: $t_{q}$ - pagal ekspertą eilutèje sutapimų skaičius.

Konkordancijos koeficientas apskaičiuojamas pagal 9 formulę.

$$
W=\frac{12 S^{2}}{m^{2}\left(k^{3}-k\right)-m T} .
$$

Konkordacijos koeficientas $W$ kinta nuo 0 iki $1(0<W<1)$; 0 reiškia visišką nesuderinamumą; 1 - visišką suderinamumą. Gautus rezultatus patikriname naudojantis 10 formule palyginant su Chi kvadrato reikšme ar yra rezultatai statistiškai reikšmingi.

$$
\chi^{2}=W m(k-1)
$$

Apskaičiuojant duomenis pagal ekspertų įvertinimus, taip pat tuo pat metodu bus apskaičiuoti vartotojų, kurie yra lojalūs grožio ir sveikatos prekių įmonėms socialiniuose tinkluose, apklausos metu gauti duomenys. Anketavimo metodas yra patogus, palyginus nebrangus, greitas ir pakankamai tikslus tyrimo metodas vartotoju nuomonei sužinoti. Anketinès apklausos metodai priskiriami prie tarpinių, kurie gali būti kokybiniai ir kiekybiniai. Kaip ir minèta anksčiau buvo pasirinkti 4 ekspertu grupè, taip pat apklausti ir 4 lojalūs vartotojai. Apklausa leido ištirti prekių ženklų ar pardavèjų, vartotojų santykius ir ịsitraukimą bei socialinių tinklų ịtaką vartotojų lojalumui. Šių dviejų tyrimų rezultatai bus palyginti ir įvertinti skirtumai ir panašumai.

Anketavimo tyrime naudojama analizè ir aprašomieji klausimai. Lojalumu ir pasitikejjimu pagrįsti susitarimo teiginiais siekiama patikrinti teoriją, ar klientai, užsiimantys prekės ženklais per socialinių tinklų svetaines, yra lojalūs ir ar jie pasitiki internete gaunama informacija. Apklausa buvo labai struktūruota ir joje buvo naudojami uždari klausimai, siekiant užtikrinti greitą dalyvių atsakymą. Klausimyną sudarè trys dalys; 1-oje dalyje dalyvių buvo paprašyta pasakyti, kaip dažnai jie naudojasi internetu ir socialiniais tinklais per dieną, kokias platformas naudoja dažniausiai, 2-oje dalyje dalyvių buvo paprašyta sureitinguoti priežastis, dèl ko vartotojai stipriai dalyvauja ir seka pardavëjus/gamintojus/prekès ženklus socialiniuose tinkluose. Priežastys: greita komunikacija su klientų aptarnavimu, noras būti bendruomenès dalimi, skelbti apžvalgas/įvertinimus/reitingus apie ir produkto kokybę, išvaizdą ir savybes, dalyvauti konkursuose, skaityti apžvalgas/atsiliepimus apie produktus ir paslaugas, noras gauti bendrą informaciją apie naujus produktus, gauti nuolaidas. 3-oje dalyje paprašyta dalyvių nurodyti savo reakciją $i$ teiginius, susijusius su pasitikejjimo ir lojalumo elgesiu. Pirmasis teiginys teigia, jog vartotojai skleidžia teigiamus dalykus apie prekès ženklus per socialinę žiniasklaidą, o antrasis teiginys - jie rekomenduoja prekès ženklus savo draugams per savo socialinių tinklų profilius.

Antrasis panaudotas tyrimo metodas - TOPSIS metodas. Šis metodas vadinamas variantų racionalumo nustatymu artumo idealiajam taškui metodu, kurio metodika pagrịsta, kad optimali alternatyva turi mažiausią 
atstumą nuo idealaus sprendimo ir didžiausią atstumą nuo neigiamai idealaus sprendimo (Simanavičienė, 2011). Pirmuoju žingsniu turimus duomenis normalizuojame pagal 11 formulę ir sudarome normalizuotą matricą.

$$
n_{i j}=\frac{x_{i j}}{\sqrt{\sum_{i=1}^{m} x_{i j}^{2}}},
$$

čia: $n_{i j}$ - normalizuota reikšmè, $x_{i j}$ - kriterijaus dydis.

Iš gautų reikšmių sudarome svertinè normalizuota matrica. Šioje matricoje jau atsispindi kriterijų svoriai.

$$
v_{i j}=w_{j} n_{i j},
$$

čia: $v_{i j}$ - svertinè reikšmè, $w_{j}-\mathrm{j}$ kriterijaus svoris.

Kitame žingsnyje sudaromi „geriausios įmanomos “ $\mathrm{V}^{+}$ir „blogiausios įmanomos“ $\mathrm{V}$ - alternatyvų modeliai pagal 13 ir 14 formulę. Užduotis yra rasti idealiausią teigiamą ir neigiamą sprendimą.

$$
\begin{aligned}
& V^{+}=\left(v_{1}^{+}, v_{2}^{+}, \ldots, v_{n}^{+}\right)=\left(\left(\max _{i} v_{i j} \mid j \in I\right),\left(\min _{i} v_{i j} \mid j \in J\right)\right) ; \\
& V^{-}=\left(v_{1}^{-}, v_{2}^{-}, \ldots, v_{n}^{-}\right)=\left(\left(\min _{i} v_{i j} \mid j \in I\right),\left(\max _{i} v_{i j} \mid j \in J\right)\right),
\end{aligned}
$$

čia: I tapatinamas su maksimizuojančiu, o J su minimizuojančiu kriterijumi.

Naudojantis 15 ir 16 formulemis apskaičiuojami idealūs teigiami ir neigiami sprendimai (Si+ ir Si-).

$$
\begin{aligned}
& S_{i}^{+}=\sqrt{\sum_{j=1}^{n}\left(v_{i j}-v_{i}^{+}\right)^{2}}, \quad i=1,2, \ldots, m ; \\
& S_{i}^{-}=\sqrt{\sum_{j=1}^{n}\left(v_{i j}-v_{i}^{-}\right)^{2}}, \quad i=1,2, \ldots, m .
\end{aligned}
$$

Galutiniu TOPSIS metodo žingsniu nustatomas kiekvienos $i$-osios alternatyvos santykinis atstumas $P_{i}$ iki „blogiausios įmanomos“ alternatyvos, kuris skaičiuojamas 17 formule. Racionalus variantas bus tas, kurio reikšmè yra didžiausia.

$$
P_{i}=\frac{S_{i}^{-}}{S_{i}^{-}+S_{i}^{+}} .
$$

Antruoju metodu tiriamas socialinių tinklų erdvëje dalyvaujančių grožio ir sveikatos prekių mažmeninkų ir vartotojų ryšys. Kriterijai kuriais norima išsiaiškinti tyrimo objektų - „Drogas“, „Eurokos“, „Douglas“, „Kosmada“ - ryši tarp vartotojo ir pardavèjų per socialinių tinklų prizmę yra: „Youtube“ video įrašų peržiūrų skaičius nuo prisijungimo datos, „Instagram“ sekejjų skaičius, „Instagram“ paskutinių 10 ịrašų komentarų skaičius, „Instagram“ vidutinis 10 ịrašų ,patinka“ skaičius, „Instagram“ pažymėtjimų vartotojų nuotraukose skaičius, „Facebook“ sekèjų skaičius, „Facebook“ paskutinių 10 ịrašų komentarų skaičius, „Facebook“ vidutinis 10 įrašų „patinka“" skaičius, „Facebook“ vidutinis 10 pasidalintų ịrašų skaičius.

Naudojant TOPSIS metodą, atsižvelgus ị pateiktus kriterijus suranguojami tiriamieji oblektai ir suformuluojamos išvados.

\section{Tyrimo rezultatų apžvalga}

Apklausos tyrimo pirmoje dalyje dalyvių buvo paklausta, kiek laiko naudojasi internetu kiekvieną dieną. Visi teige esantys kasdieniai interneto vartotojai. 50 proc. respondentų internetu naudojasi daugiau nei penkias valandas kiekvieną dieną. Nors socialinių tinklų svetainès nėra vienintelès priežastys, leidžiančios leisti laiką internete, visi dalyviai turi paskyrą bent vienoje socialinių tinklų svetainèje, kurioje praleidžia vidutiniškai apie 2 valandas per dieną. Visi apklausos dalyviai turi paskyrą „Facebook“ socialinio tinklo svetainejje, 80 proc. dalyvių turi paskyras „Instagram“, „LinkedIn“, YouTube“ paskyrose. Ekspertų vertinimai patikrinti naudojant ekspertų kompetencijos koeficiento skaičiavimus. Visi ekspertų kompetencijos koeficientai įeina ì tenkinamą intervalą ir gali būti naudojami tolimesniems skaičiavimas. Kendall konkordancijos koeficientas atitinka 9,39 kuris didesnis už Chi kvadrato reikšmę. Hipotezę $\mathrm{H}_{0}$ atmetame, dèl to galime teigti, kad Kendall konkordancijos koeficientas yra tinkamas skaicius ir patikimas, ekpspertų vertinimai panašūs ir gali būti naudojami tolimesniems tyrimams. Tuo pat principu atlikus apskaičiavimus su vartotojų apklausos duomenimis, nustatyta, kad nuomonès yra suderintos, 
Kendall konkordacijos koef. atitinka 8,02 kuris taip pat didesnis už Chi kvadrato reikšmę. Hipotezė $\mathrm{H}_{0}$ atmetama ir duomenys gali būti naudojami tolimesniams tyrimams. Ekspertų ir vartotojų priežastys sekti įmones ar prekès ženklus socialiniuose tinkluose yra suderintos tarpusavyje. Ekspertų ir vartotojų nuomone svarbiausia priežastis yra apžvalgŭ, atsiliepimų apie produktus ir paslaugas skaitymas ir naudojimas. Naujus vartotojus labiau pritraukia teigiami atsiliepimai apie produktą nei atsiliepimų trūkumas. Ekspertų nuomene dar labai svarbios priežastys yra greitas susisiekimas su klientų aptarnavimu ir bendros informacijos apie naujienas gausa ir prieinamumas. Vartotojai turi galimybę susisiekti, sužinoti apie dominamas prekes ar paslaugas bet kuriuo paros metu ir neatvykstant ị parduotuvę, taip pat vartotojai gali užsisakyti dominančią produkciją tiesiai ị namus taupant laiko ir finansų kaštus. Kaip ir ekspertai, anketos dalyviai taip pat nustate, kad greita komunikacija yra labai svarbi priežastis sekti įmones per socialinius tinklus. Pagal apklausos dalyvius dalyvavimas konkursuose ir specialiu nuolaidų gavimas yra mažiausiai reikšmingos sekant socialinuose tinkluose i̇monę ar prekès ženklą. 3-ioje apklausos dalyje rezultatai nurodo kad dauguma dalyvių palieka teigiamus komentarus ir atsiliepimus apie prekès ženklus ir pardavèjus per socialinius tinklus, tačiau jie retai siunčia rekomendacijas draugams.

TOPSIS metodu duomenys normalizuojami ir sudaryta nauja matrica. Matricos normalizavimui naudota 11 formulè. Sekančiame žingsnyje iš gautu reikšmių sudaryta svertinè normalizuota matrica. Šioje matricoje jau atsispindi kriterijų svoriai. Visiems kriterijams naudojome vienodą svorị - 0,11 , nes šio tyrimo kriterijų svoriu ekspertai nevertino. Naudojant TOPSIS metodą, atsižvelgus i pateiktus kriterijus, stipriausią ryšị su vartotojais socialinių tinklu platformose turi grožio ir sveikatos prekių įmonè yra „Drogas”, antroje vietoje „Eurokos”, trečioje - „Dougas”. ir ketvirtoje - „Kristiana”. Aukščiausiu tyrimo rezultatu pasižyminti i̇mone „Drogas“ turi daugiausia, palyginti su kitomis tyrimo įmonėmis, sekejjų skaičiu platformose „Facebook“ ir „Instagram“. Pagal duomenis „Drogas” aktyviai ịtraukia vartotojus ị savo ịrašus, kurie susilaukia daugiausia komentarų ir „širdute” pažymėjimų, tai galëjo lemti konkursų patrauklumas, nors lyginant su „Eurokos”, konkursų kiekies sekančioje įmonèje yra didesnis. Taip pat „Drogas“ vartotojų pažymėjimas „patinka” ant ịrašų „Facebook” platformoje yra lyderiaujantis, tačiau „Eurokos” komantarų skaičius įrašuose „Facebook” platformoje lenkia kitas tiriamas įmones. „YouTube” platformoje „Douglas” ịrašu peržiūros yra didžiausios, nes ši įmoné pateikia pamokų tipo įrašus, reklamuojanti ne tik produktą bet ir kaip ji naudoti. Kitas svarbus rodiklis, kuris turi sąlyginai didesnę reikšmę yra vartotojų pažymėjimai įmonès žymę - ,grotažymę“ savo įrašo aprašyme. Tai ne tik plečia vartotojų ratą, kelia pasitikejjimo lygi, bet ir rodo vartotojo lojalumo įmonei lygị, nes vartotojas savo paskyroje ịkeldami ịrašą praneša savo sekejjams, kad jam įmonés produktas naudingas, ir jị reklamuoja kitiems.

\section{Išvados}

Mokslinėje literatūroje yra nemažai tyrimų apie vartotojų lojalumą; tačiau tyrimų kiekis vertinant vartotojų lojalumą per socialinių tinklų erdvę yra labai ribotas. Ištirtoje literatūroje aptariama, kad vien vartotojų pirkimas nèra geriausias ilgalaikès sẻkmès būdas, taip pat svarbu sukurti vartotojams vertę. Papildomą vertę vartotojams sukurti yra sunku, nes socialinių tinklų naudojimasis auga, vartotojai vis labiau ịsitraukia ị interneto erdvę ir palaiko ryši per socialinius tinklus. Vartotojai naudojasi platformomis, tokiomis kaip „Facebook“, „YouTube“ ir „Instagram“, norẻdami palaikyti ryši su naujų produktų pirkimo rekomendacijomis, apžvalgomis, mokymais. Nuolat plečiantis grožio industrijai ir socialinei tinklu erdvei tampant vis reikšmingesne visuomenei, tyrimai rodo, kad vartotojų pirkimui daro itaką socialiniai tinklai. Socialiniai tinklai suteikia vartotojams preigą prie nesibaigiančios informacijos rinkimo ir suvartojimo, o įmonèms prieigą prie naujausių tendencijų, informacijos apie konkurentus, didesnę ir spartesnę apyvartą, pigesnę marketingo strategiją, informacijos apie įmone sklaidą.

Ekspertinio vertinimo metu gauti rezultatai rodo, kad patikrinus statistinį reikšmingumą, reikšmè nepatenka ị chi reikšmę ir hipoteze H0 atmetama, galima teigti, jog ekspertų vertinimai panašūs ir konkordancijos koeficientas nelygus nuliui. Tie patys skaičiavimai buvo atlikti ir 4 vartotojų anketos duomenims tirti. Anketos rezultatai rodé, kad visi dalyviai yra kasdieniai interneto vartotojai. 50 proc. respondentų internetu naudojasi daugiau nei penkias valandas kiekvieną dieną ir turi „Facebook“ paskyrą. Ekspertų ir vartotojų priežastys sekti įmones ar prekės ženklus socialiniuose tinkluose yra suderintos tarpusavyje. Ekspertu ir vartotojų nuomone svarbiausia priežastis yra apžvalgŭ, atsiliepimų apie produktus ir paslaugas skaitymas. Ekspertų nuomene taip pat svarbios priežastys yra greitas susisiekimas su klientu aptarnavimu ir bendros informacijos apie naujienas gausa ir prieinamumas. Dalyvių apklausos rezultatai nustate, kad dalyvavimas konkursuose ir specialių nuolaidu gavimas yra mažiausiai reikšmingos sekant socialinuose tinkluose įmonę ar prekès ženklą.

TOPSIS tyrimu auksčiausiu rezultatu pasižyminti i̇monė „Drogas“ turi daugiausia sekëju platformose „Facebook“ ir „Instagram“. Imoné aktyviai ịtraukia vartotojus ị savo ịrašus, kurie susilaukia daugiausia komentarų, tai galëjo lemti konkursų patrauklumas. Antroje vietoje pagal rangą yra „Eurokos“, kuris lenkia kitas tiriamas įmones įrašų komantarų skaičiumi „Facebook” platformoje, dèl skelbiamų konkursų skaičiaus. Trečioje rango vietoje esanti įmonẻ „Douglas“ siekia didžiausias ịrašų peržiūras „YouTube” platformoje, dèl skelbiamų pamokų tipo ịrašų, kurie reklamuoja ne tik produktą bet ir kaip ji naudoti. Atlikus įmonių socialiniuose tinkluose analizę, nustatyta, kad nè viena įmonè neturi savo mobiliosios programélès, kurios dẻka vartotojai galètu ịsigyti prekes bet kokiu laiku, rašyti ir skaityti atsiliepimus. Plètra skatintų vartotojų rato plètrą, pasitikėjimo lygị. 


\section{Literatūra}

Asperen, M. Van, Rooij, P. De, \& Dijkmans, C. (2018). Engagement-Based Loyalty: The Effects of Social Media Engagement on Customer Loyalty in the Travel Industry Engagement-Based Loyalty: The Effects of Social Media. International Journal of Hospitality \& Tourism Administration, 19(1), 78-94. https://doi.org/10.1080/15256480.2017.1305313

Baramidze, T. (2018). Vytautas Magnus University Faculty of economics and management marketing department the effect of influencer marketing on customer behavior. The case of youtube influencers in makeup industry Master Diploma Paper Programme: Marketing and International Com.

https://eltalpykla.vdu.lt/bitstream/handle/1/36339/tamar_baramidze_md.pdf?sequence=3\&isAllowed=y

Blut, M., Evanschitzky, H., Vogel, V., \& Ahlert, D. (2007). Switching barriers in the four-stage loyalty model. In NA Advances in consumer research (Vol. 34, pp. 726-734), MN - Association for Consumer Research. http://www.acrwebsite.org/volumes/12712/volumes/v34/NA-34

Cossío Silva, F. J., \& Revilla Camacho, M. A. (2016). Value co-creation and customer loyalty. Journal of Business Research, 69(5), 1621-1625. https://doi.org/10.1016/j.jbusres.2015.10.028

Craig, E. M. (2007). Changing paradigms: managed learning environments and Web 2.0. Campus-Wide Information Systems, 24(3), 152-161. https://doi.org/10.1108/10650740710762185

Erdogmus, I. E., \& Cicek, M. (2012). The Impact of Social Media Marketing on Brand Loyalty. Procedia - Social and Behavioral Sciences, 58, 1353-1360. https://doi.org/10.1016/j.sbspro.2012.09.1119

Feng, S., Wong, Y. K., Wong, L. Y., \& Hossain, L. (2019). The Internet and Facebook Usage on Academic Distraction of College Students. Computers \& Education, 134, 41-49. https://doi.org/10.1016/j.compedu.2019.02.005

Hwang, K., \& Zhang, Q. (2018). Influence of parasocial relationship between digital celebrities and their followers on followers' purchase and electronic word-of-mouth intentions, and persuasion knowledge. Computers in Human Behavior, 87, 155-173. https://doi.org/10.1016/j.chb.2018.05.029

Kandampully, J., \& Suhartanto, D. (2000). Customer loyalty in the hotel industry: the role of customer satisfaction and image. International Journal of Contemporary Hospitality Management, 12(6), 346-351. https://doi.org/10.1108/09596110010342559

Kim, M. K., Wong, S. F., Chang, Y., \& Park, J. H. (2016). Determinants of customer loyalty in the Korean smartphone market: Moderating effects of usage characteristics. Telematics and Informatics, 33(4), 936-949. https://doi.org/10.1016/j.tele.2016.02.006

Koetz, C. (2019). Managing the customer experience: a beauty retailer deploys all tactics. Journal of Business Strategy, 40(1), 10-17. https://doi.org/10.1108/JBS-09-2017-0139

Legendre, P. (2005). Species associations: the Kendall coefficient of concordance revisited. Journal of Agricultural, Biological, and Environmental Statistics, 10(2), 226-245. https://doi.org/10.1198/108571105X46642

McKenna, K. Y. A., \& Bargh, J. A. (1999). Causes and Consequences of Social Interaction on the Internet: A Conceptual Framework. Media Psychology, 1(3), 249-269. https://doi.org/10.1207/s1532785xmep0103_4

Mohammadi, H. (2015). A study of mobile banking loyalty in Iran. Computers in Human Behavior, 44, $35-47$. https://doi.org/10.1016/j.chb.2014.11.015

Ngobo, P. V. (2017). The trajectory of customer loyalty: an empirical test of Dick and Basu's loyalty framework. Journal of the Academy of Marketing Science, 45(2), 229-250. https://doi.org/10.1007/s11747-016-0493-6

Nisar, T. M., \& Whitehead, C. (2016). Brand interactions and social media: Enhancing user loyalty through social networking sites. Computers in Human Behavior, 62, 743-753. https://doi.org/10.1016/j.chb.2016.04.042

Oliver, R. L. (1999). Whence Consumer Loyalty? Journal of Marketing, 63, 33. https://doi.org/10.2307/1252099

Reichheld, F. (2001). Prescription for cutting costs. Bain \& Company.

Sangeetha, S., \& Jawahar Ran, K. (2015). A study on loyalty and its dimensions. 5(4), 2001-2003.

Simanavičienè, R. (2011). Kiekybiniu daugiatiksliu sprendimo priemimo metody jautrumo analizé. Technika. https://doi.org/10.20334/1973-M

Statista. (2019). YouTube: annual beauty content views 2018. Retrieved 1 December 2019, from https://www.statista.com/statistics/294655/youtube-monthly-beauty-content-views/

Walton, S. (1990). Made in America: My Story, with J. Huey. Retrieved 22 October 2019, from https://www.forbes.com/sites/robertreiss/2014/04/21/how-top-ceos-transform-companies-around-the-customer-like-thenew-kentucky-derby-videoboard/\#1a815fc532ac

Zeng, B., \& Gerritsen, R. (2014). What do we know about social media in tourism? A review. TMP, 10, 27-36. https://doi.org/10.1016/j.tmp.2014.01.001 


\title{
ASSESSMENT OF THE LOYALTY OF BEAUTY AND HEALTH CONSUMER IN THE SOCIAL SPACE
}

\section{Vilmantè LEIŠYTĖ, Valentina PELECKIENĖ}

\begin{abstract}
The paper aims to explore how consumer loyalty to beauty and health products can be achieved and maintained through the prism of social networks. Although there is a lot of research on consumer loyalty however, the amount of research measuring consumer's loyalty through the social networking space is very limited. The studied literature discusses that customer buying alone is not the best way to long-term success, it is also important to create value for consumers. This study presents the relationship between consumer loyalty to the company through the social networking space, and examines consumer behavior and the reasons for branding on the Internet. Peer review and TOPSIS methods were used for research. Active follow-up of the company research results on social networks stimulates consumer loyalty, trust, and revenue turnover. There are inevitable limitations to the study. Aggregated results may become irrelevant in the future due to changes in technology. Given that social networking sites are a new phenomenon, further research is possible.
\end{abstract}

Keywords: consumer loyalty, beauty and health products, brand, social networks, TOPSIS, expert evaluation method. 